\title{
Analysis of Structural and Optical Features of CuO Nanoparticles Synthesized at Different Molarities
}

\author{
C. Kalita ${ }^{1^{*}}$, S. Karmakar ${ }^{2}$ \\ ${ }^{1}$ Dept. of Instrumentation and USIC, Gauhati University, Guwahati, India \\ ${ }^{2}$ Dept. of Instrumentation and USIC, Gauhati University, Guwahati, India \\ *Corresponding Author: chandrama4u@gmail.com, Tel.: +0-9508381686
}

Available online at: www.isroset.org

Received: 16/Mar/2018, Revised: 22/Mar/2018, Accepted: 14/Apr/2018, Online: 30/Apr/ 2018

\begin{abstract}
The sol-gel method has been implemented to synthesize $\mathrm{CuO}$ nanoparticles at $100^{\circ} \mathrm{C}$.The monoclinic phase structure of $\mathrm{CuO}$ nanoparticles has been confirmed by X-ray Diffraction (XRD) pattern. Crystal size and dislocation density of the nanoparticles have been estimated from XRD data. Optical band gaps have been calculated from optical absorption spectra. The chemical composition of the nanoparticles has been investigated with using fourier transform infra red (FTIR) spectroscopy. The crystal surfaces of the nanoparticles have been investigated by scanning electron microscopy (SEM).
\end{abstract}

Keywords-Nanoparticles, XRD, optical band gap, FTIR, SEM

\section{INTRODUCTION}

Nanoparticles differ from bulk materials due to their peculiar electronic, optical and chemical features. Copper oxide $(\mathrm{CuO})$ nanoparticles are extensively utilized in plenty of applications such as gas sensor, photo catalyst, antimicrobial, solar cells, humidity sensor, toxic element remover from water [1-13]. Numerous methods are used to synthesized $\mathrm{CuO}$ nanoparticles such as chemical bath deposition, vapour deposition, microwave assist synthesis, hydrothermal synthesis, sol-gel, spray pyrolysis solid state thermal decomposition [14-20]. The sol-gel method is one of the cost-effective methods for preparing $\mathrm{CuO}$ nanoparticles. In this paper, we have prepared $\mathrm{CuO}$ nanoparticles with the help of sol-gel method and analysed its different structural and optical features.

This paper has been arranged into four segments Introduction, Materials and Methods, Results and Discussion and Conclusion. Introduction segment gives the brief review of literature related to our present work. Materials and Method segment contains the materials used for the preparation of $\mathrm{CuO}$ nanoparticles and details of preparation procedure of $\mathrm{CuO}$ nanoparticles at different molarities by sol-gel method with special reference to characterization tools. Results and Discussion segment provides a brief detail on the characterizations of the $\mathrm{CuO}$ nanoparticles and analysis and discussion of the results obtained. Conclusion segment provides major conclusions drawn from the results.

\section{MATERIALS AND METHODS}

All the required materials for synthesizing $\mathrm{CuO}$ nanoparticles by the sol-gel method, such as $\mathrm{CuCl}_{2} \cdot 2 \mathrm{H}_{2} \mathrm{O}$, $\mathrm{NaOH}$ and glacial acetic acid were bought from the market with the highest purity. The aqueous solution of $\mathrm{CuCl}_{2} \cdot 2 \mathrm{H}_{2} \mathrm{O}$ $(0.2 \mathrm{M})$ was prepared in $50 \mathrm{ml}$ DI water dissolving the required amount of $\mathrm{CuCl}_{2} \cdot 2 \mathrm{H}_{2} \mathrm{O}$ in a beaker. Dropwise addition of $1 \mathrm{ml}$ of glacial acetic acid was done to the above solution with constant stirring and then heated to $100^{\circ} \mathrm{C}$. The colour of the aqueous solution turned from blue to green. 8.5 $\mathrm{pH}$ was maintained by dropwise addition of $8 \mathrm{M} \mathrm{NaOH}$ solution to the above solution. A change in colour of the solution was observed and a black precipitate was formed. The precipitate was filtered and washed 4 times with deionized water. Then the precipitate was dried in air and converted into powder using mortar. The powders were used for further analysis and characterization of $\mathrm{CuO}$ nanoparticles.

A similar method was applied to synthesized $\mathrm{CuO}$ nanoparticles from $0.4 \mathrm{M}$ and $0.6 \mathrm{M} \mathrm{CuCl}_{2} \cdot 2 \mathrm{H}_{2} \mathrm{O}$ aqueous solution.

Structural characterization of prepared $\mathrm{CuO}$ nanoparticles were done by XRD using Philips X'pert Diffractometer with $\mathrm{CuK} \alpha$ radiation $(\lambda=1.5406 \dot{A})$. Carry 300 scan UV-Visible spectrophotometer was used to measure optical absorption spectra. Fourier Transform infra red (FTIR) spectra of $\mathrm{CuO}$ nanoparticles were obtained from SHIMADZU in the wave length range $400-4000 \mathrm{~cm}^{-1}$. The morphology of prepared 
$\mathrm{CuO}$ nanoparticles was studied by Scanning electron microscope, ZEISS, SIGMA.

\section{RESULTS AND DISCUSSION}

\section{A. Structural Analysis}

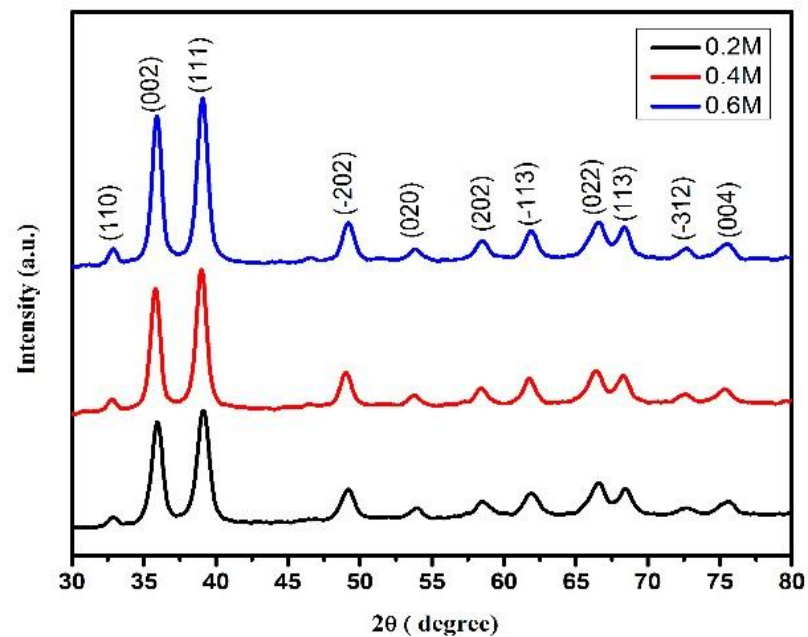

Fig 1: $\mathrm{XRD}$ pattern of $\mathrm{CuO}$ nanoparticles prepaped at $0.2 \mathrm{M}, 0.4 \mathrm{M}$ and $0.6 \mathrm{M}$

X-Ray Diffraction pattern is used for determining the structure and phase of prepared $\mathrm{CuO}$ nanoparticles. Fig. 1 shows the XRD diffraction pattern of prepared $\mathrm{CuO}$ nanoparticles at different molarities $(0.2 \mathrm{M}, 0.4 \mathrm{M}$ and $0.6 \mathrm{M})$. The diffraction pattern exhibits clear peaks centred at various angles corresponds to (110), (002), (111), (-202), (020), (202), (-113), (022), (113), (-312) and (004) planes as shown in Table1. All the peaks in the diffraction pattern show the prepared $\mathrm{CuO}$ nanoparticles are of monocline structure. The peaks are matched with the standard data of ICDD card no. 89-5895. The Debye-Scherrer's equation is used to find the crystallite size (D) of prepared samples [21].

$$
D=\frac{K \lambda}{\beta \cos \theta}
$$

Where $K$ is a constant and equal to $0.9, \lambda=$ wavelength of $\mathrm{X}$ ray radiation ( $\lambda=1.54056 \AA$ for $\mathrm{CuK}_{\alpha}$ radiation), $\beta=\mathrm{FWHM}$ (full width at half maximum, in radian) and $\theta=$ the Bragg's diffraction angle. The calculated values of crystallite size are given in Table 1.

The dislocation density of $\mathrm{CuO}$ nanoparticles has been estimated by using the equation [22]

$$
\text { Dislocation Density }(\delta)=1 /\left(\mathrm{D}^{2}\right)
$$

Where $D$ is the crystallite size. The calculated values of dislocation density of the $\mathrm{CuO}$ nanoparticle samples are given in Table 1.

Table1.Structural parameters of $\mathrm{CuO}$ nanoparticles prepared at various

\begin{tabular}{|c|c|c|c|c|}
\hline Molarity & Angle & hkl & $\begin{array}{l}\text { Size } \\
\text { obtained by } \\
\text { Debye } \\
\text { Scherrer } \\
\text { formula }\end{array}$ & $\begin{array}{l}\text { Dislocation } \\
\text { Density }\end{array}$ \\
\hline & $\left(2 \theta^{0}\right)$ & & (nm) & $\left(\delta \times 10^{16} \mathrm{~m}^{2}\right)$ \\
\hline \multirow[t]{9}{*}{$\mathrm{CuO}(0.2 \mathrm{M})$} & 32.86 & (110) & 10.99138 & 0.828388 \\
\hline & 35.86 & (002) & 9.583741 & 1.089603 \\
\hline & 39.21 & (111) & 9.679324 & 1.06819 \\
\hline & 49.24 & $(-202)$ & 7.577513 & 1.74295 \\
\hline & 53.99 & (020) & 9.566095 & 1.093626 \\
\hline & 58.99 & (202) & 7.145324 & 1.960173 \\
\hline & 61.96 & $(-113)$ & 8.040692 & 1.547931 \\
\hline & 66.58 & (022) & 8.246726 & 1.47155 \\
\hline & 68.53 & (113) & 7.524922 & 1.767398 \\
\hline \multirow[t]{9}{*}{$\mathrm{CuO}(0.4 \mathrm{M})$} & 32.89 & (110) & $\mathbf{1 1 . 9 1 2 5 7}$ & 0.705224 \\
\hline & 35.89 & $(002)$ & 10.79271 & 0.859166 \\
\hline & 39.09 & (111) & 9.668031 & $\mathbf{1 . 0 7 0 6 8 6}$ \\
\hline & 49.24 & $(-202)$ & 8.659733 & 1.334533 \\
\hline & 53.87 & (020) & 7.417666 & 1.818879 \\
\hline & 58.56 & (202) & 9.035591 & 1.225816 \\
\hline & 61.94 & $(-113)$ & 9.911643 & 1.018702 \\
\hline & 66.57 & (022) & 7.530069 & 1.764983 \\
\hline & 68.36 & (113) & 8.985342 & 1.239565 \\
\hline \multirow[t]{9}{*}{$\mathrm{CuO}(0.6 \mathrm{M})$} & 32.74 & (110) & 12.43965 & 0.646729 \\
\hline & 35.85 & (002) & 11.34733 & $\mathbf{0 . 7 7 7 2 3 2}$ \\
\hline & 39.1 & (111) & 10.02501 & 0.995793 \\
\hline & 49.1 & $(-202)$ & 10.0241 & 0.995972 \\
\hline & $\mathbf{5 3 . 8 5}$ & (020) & 8.506046 & 1.383193 \\
\hline & 58.4 & (202) & 8.616924 & $\mathbf{1 . 3 4 7 8 2 6}$ \\
\hline & 61.71 & $(-113)$ & 9.838855 & $\mathbf{1 . 0 3 3 8 3}$ \\
\hline & 66.4 & $(\mathbf{0 2 2})$ & 8.176828 & 1.496817 \\
\hline & 68.25 & (113) & 9.254641 & 1.168474 \\
\hline
\end{tabular}
molarity

\section{B. Optical Absorption Analysis}

Different optical properties of the prepared $\mathrm{CuO}$ nanoparticles were studied by recording optical absorbance spectra in the range $200-800 \mathrm{~nm}$. The information of optical absorbance and band gap energy of a material predicts the area in which it can be used. 


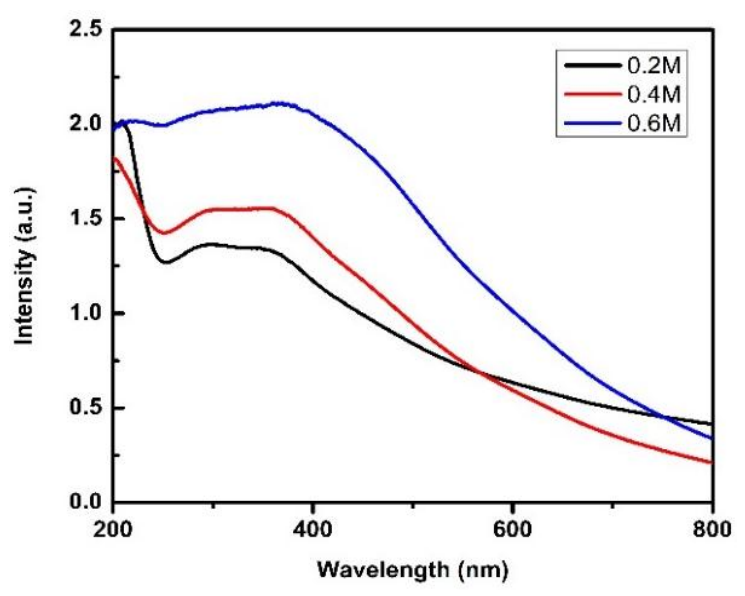

Fig 2. Absorption spectra of $\mathrm{CuO}$ nanoparticles prepared at $0.2 \mathrm{M}$, $0.4 \mathrm{M}$ and $0.6 \mathrm{M}$

The Fig 2. shows optical absorption spectra of $\mathrm{CuO}$ nanoparticles synthesized at different molarities $(0.2 \mathrm{~m}, 0.4 \mathrm{M}$ and $0.6 \mathrm{M}$ ) [23-24].

The optical band gap energy $\left(E_{\mathrm{g}}\right)$ is calculated by using Tauc's formula [25]

$$
(\alpha h v)^{1 / n}=A(h v-E g)
$$

Where $\boldsymbol{\alpha}$ is the absorption co-efficient, $h \boldsymbol{\nu}$ is the incident photon energy, $A$ is a constant. For direct band gap material, $\mathrm{n}=1 / 2$. The band gap energy has been estimated by plotting graph $(\boldsymbol{\alpha} h \boldsymbol{\nu})^{2}$ versus $h \boldsymbol{\nu}$ and then extrapolating the linear region of plots as shown in Fig 3. The band gap energy of $\mathrm{CuO}$ nanoparticles prepared at $0.2 \mathrm{M}, 0.4 \mathrm{M}, 0.6 \mathrm{M}$ are estimated as $4.94,4.48$ and $2.76 \mathrm{eV}$ respectively.

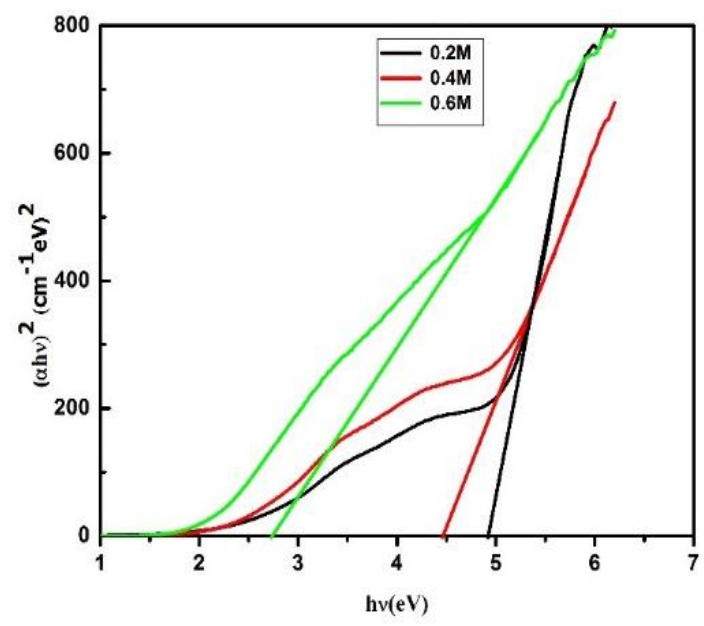

Fig 3. $(\boldsymbol{\alpha} h \boldsymbol{\nu})^{2}$ vs $h \boldsymbol{\nu}$ spectra of $\mathrm{CuO}$ nanoparticles prepared at $0.2 \mathrm{M}, 0.4 \mathrm{M}$ and $0.6 \mathrm{M}$

\section{Fourier Transform Infrared (FTIR) Analysis}

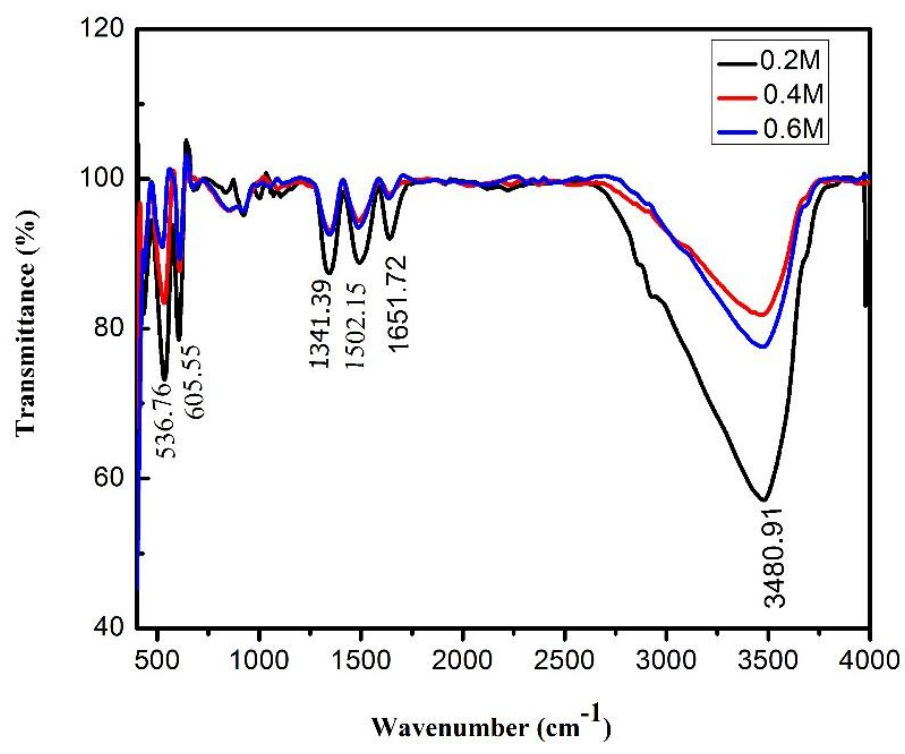

Fig 4. FTIR spectra of $\mathrm{CuO}$ nanoparticles prepared at $0.2 \mathrm{M}, 0.4 \mathrm{M}$ and $0.6 \mathrm{M}$

$\mathrm{KBr}$ pellets technique was used to find the FTIR spectra of prepared $\mathrm{CuO}$ nanoparticles. Fig.4 shows the FTIR spectra of $\mathrm{CuO}$ nanoparticles prepared at $0.2 \mathrm{M}, 0.4 \mathrm{M}$ and $0.6 \mathrm{M}$ respectively in the range of $4000-400 \mathrm{~cm}^{-1}$. Formation of highly pure $\mathrm{CuO}$ nanoparticles was confirmed by bands at around $605.55,536.76 \mathrm{~cm}^{-1}$ of FTIR spectra which are formed due to vibrations of $\mathrm{Cu}$ (II)-O bonds. The distinctive peaks of $\mathrm{CuO}$ are located in between $984 \mathrm{~cm}^{-1}$ to $426 \mathrm{~cm}^{-1}$. A wide absorption band at around $3480.91 \mathrm{~cm}^{-1}$ is observed which occurs due to absorption of moistures by the nanoparticles. The metal-oxygen bond is observed at $1341.39 \mathrm{~cm}^{-1}$, $1502.15 \mathrm{~cm}^{-1}$ and $1651.72 \mathrm{~cm}^{-1}$ indicating the formation of $\mathrm{CuO}$ from Copper Chloride. All the allocation of peaks is in accordance with the values found in the literature [26-32].

\section{SEM Analysis}

The surface morphology and micro structure of prepared $\mathrm{CuO}$ nanoparticles were investigated with the help of SEM images as shown in figure 5. It clearly shows the almost spherical morphology of prepared $\mathrm{CuO}$ nanoparticles with a homogeneous distribution. Agglomeration of spherical $\mathrm{CuO}$ nanoparticles was also observed from the SEM images. 


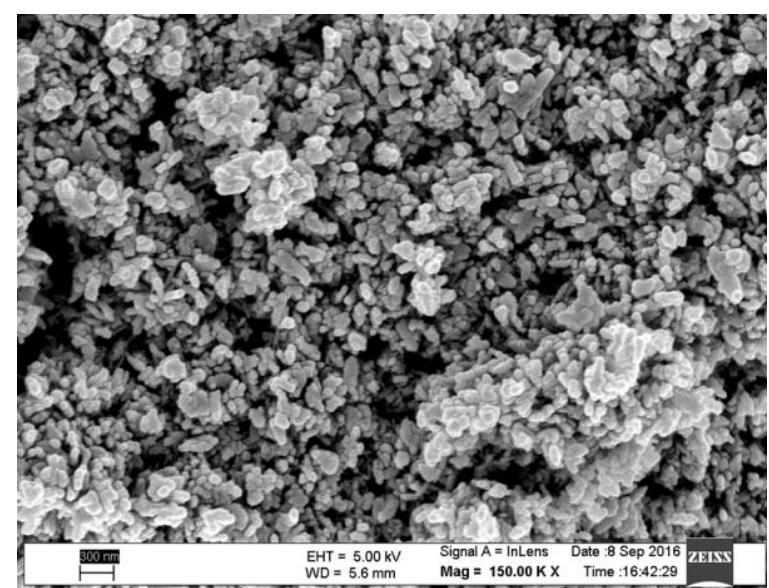

(a)

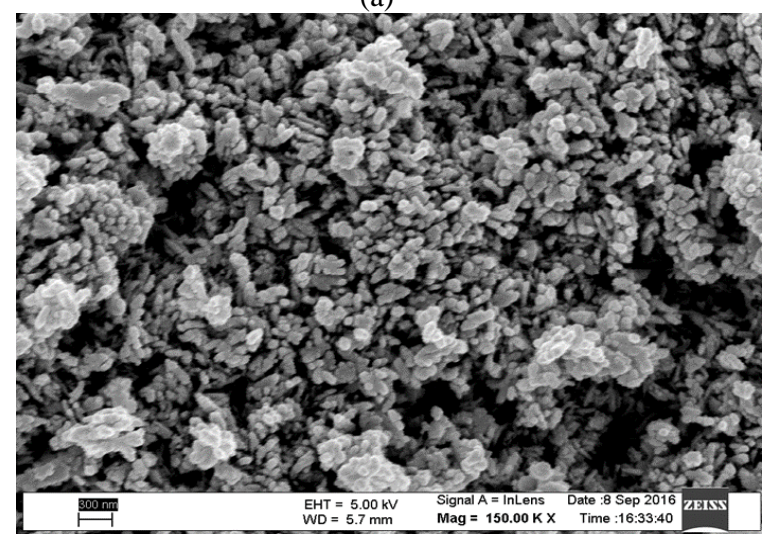

(b)

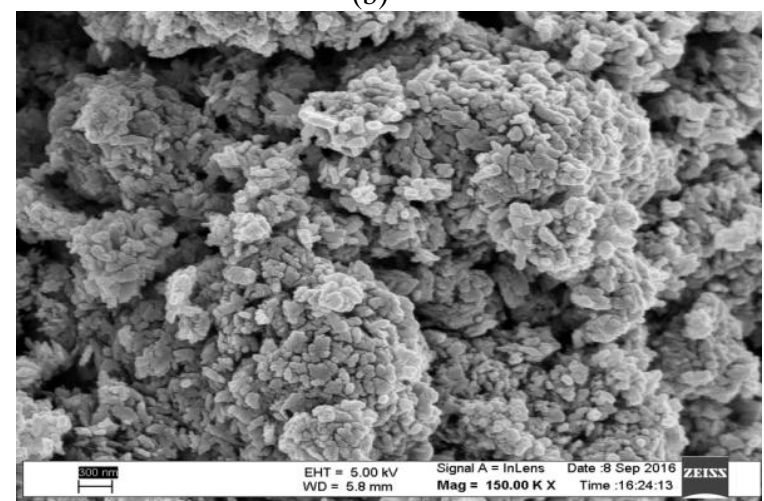

(c)

Fig 5. SEM images of $\mathrm{CuO}$ nanoparticles prepared at (a)0.2M,

(b) $0.4 \mathrm{M}$ and (c) $0.6 \mathrm{M}$ molar concentration of precursors

\section{CONClUSION AND FUTURE SCOPE}

Copper oxide nanoparticles are successfully prepared by solgel method. XRD pattern shows the prepared nanoparticles are of the monoclinic structure. It is observed that with the increase of crystallite size, the dislocation density decreases. With the increase in molarity of precursors, the band gap of prepared nanoparticles decreases. FTIR spectra show the stressing modes of the prepared samples. SEM images show the morphology of prepared $\mathrm{CuO}$ nanoparticles. We plan to study the prepared $\mathrm{CuO}$ nanoparticles as water purifier as our future work.

\section{ACKNOWLEDGMENT}

We express our sincere gratitude to SAIF, Dept. of Instrumentation \& USIC, Gauhati University and IIT Guwahati for providing different instruments facility.

\section{REFERENCES}

[1] Z. Zhu, W. Zeng, S. Cao, L. Chen, "Gas sensing property of novel flower-like nanostructure $\mathrm{CuO}$ ", Journal of Material Science:Materials in Electronics, Vol. 26, Issue. 11, pp. 9037 9043, 2015

[2] L. Liao, Z. Zhang, B. Yan, Z. Zheng, Q. L. Bao, T. Wu, C. M. Li, Z. X. Shen, J.X. Zhang, H. Gong, J.C. Li, T. Yu, "Multifunctional $\mathrm{CuO}$ nanowire devices: p-type field effect transistors and $\mathrm{CO}$ gas sensors", Nanotechnology, Vol. 20, 2009

[3] X. Li, W. Guo, H. Huang, T. Chen, M. Zhang, Y. Wang, "Synthesis and photocatalytic Properties of $\mathrm{CuO}$ Nanostructures", Journal of Nanoscience and Nanotechnology, Vol. 14 , Issue.5, pp. 3428-3432, 2014

[4] A.Azam, A. S. Ahmed, M. Oves, M.S. Khan, A. Memic, "Sizedependent antimicrobial properties of $\mathrm{CuO}$ nanoparticles against gram-positive and -negative bacterial strains", International Journal of Nanomedicine, Vol. 7, pp. 3527-3535, 2012

[5] H. Kidowaki, T. Oku, T. Akiyama, A. S. B. Jeyadevan, J. Cuya, "Fabrication and Charcterization of CuO-based Solar Cells", Journal of Materials Science Research, vol. 1, Issue. 1, 2012

[6] S.B. Wang, C. H. Hsiao, S. J. Chang, K. T. Lam, K. H. Wen, S. J. Young, S. C. Hung, B. R. Huang, "CuO Nanowire-Based Humidity Sensor”, IEEE SENSORS JOURNAL, Vol. 12, Issue. 6, pp. 1884-1888, 2012.

[7] H. Abbasian, D. Ghanbari, G. Nabiyouni, "SonochemicalAssisted Synthesis of Copper Oxide Nanoparticles and Its Application as Humidity Sensor", Journal of NANOSTRUCTURES, Vol. 3, Issue. 4, pp.429-434, 2013

[8] S. Ashonkan, V. Ponnuswamy, P. Jayamrugan, Y. V. S. Rao, "Fabrication and characterization of $\mathrm{CuO}$ nanoparticles: Its humidity sensor application", South Asian Journal of Engineering and Technology, Vol. 1, Issue. 1,pp. 11-23, 2015

[9] A. Goswami, P. K. Raul, M.K. Purkait, "Arsenic adsorption using copper (II) oxide nanoparticles", Chemical Engineering Research and Design, Vol. 90, Issue. 9, pp. 1387-1396, 2012

[10] K. J. Reddy, K. J. McDonald, H. King, "A novel arsenic removal process for water using cupric oxide nanoparticles", Journal of Colloid and Interface Science, Vol. 397, pp. 96-102, 2013.

[11] Carol A. Martinson, K. J. Reddy, "Adsorption of arsenic (III) and arsenic (V) by cupric oxide nanoparticles", Journal of Colloid and Interface Science, Vol. 336, Issue. 2, pp. 406-411, 2009

[12] E. Bazrafshan, D. Balarak, A. H. Panahi, H. Kamani, A. H. Mahvi, "FLUORIDE REMOVAL FROM AQUEOUS SOLUTIONS BY CUPRICOXIDE NANOPARTICLES”,Vol. 49, Issue. 3, pp. 233244, 2016

[13] G. Mustafa, H. Tahir, M. Sultan, N. Akhtar, "Synthesis and characterization of cupric oxide $(\mathrm{CuO})$ nanoparticles and their application for the removal of dyes", African Journal of Biotechnology, Vol. 12, Issue. 47, pp. 6650-6660, 2013

[14] K. Phiwdang, S. Suphankij, W. Mekprasart, W. Pecharapa, "Synthesis of $\mathrm{CuO}$ Nanoparticles by Precipitation Method Using 
Different Precursors", Energy Procedia, Vol. 34, pp. 740-745, 2013

[15] M. Shahmiri, N. A. Ibrahim, N. Zainuddin, N. Asim, B. Bakhtyar, A. Zaharim, k. Sopian, "Effect of $\mathrm{pH}$ on the synthesis of $\mathrm{CuO}$ Nanosheets by Quick Precipitation Method", WSEAS TRANSACTIONS on ENVIRNONMENT and DEVELOPMENT, Vol. 9, Issue. 2, pp.137-146, 2013

[16] N. G. Telkapalliwar, D. M. Borikar, K. G. Rewatkar, "MICROWAVE ASSISTAED SYNTHESIS OF COPPER OXIDE NANOPARTICLES: OPTICAL AND STRUCTURAL CHARCTERIZATION", INTERNATIONAL JOURNAL OF ADVANCE RESEARCH AND INNOVATIVE IDEAS IN EDUCATION, Vol. 2, Issue. 2, pp. , 2016

[17] K. Kannaki, P. S. Ramesh, D. Geetha, "Hydrothermal synthesis of $\mathrm{CuO}$ Nanostructure and Their Characterizations", International Journal of Scientific \& Engineering Research, Vol. 3, Issue. 9, 2012

[18] Y. Aparna, K. V. Rao, P. S. Subharao, "Preparation and Characterization of $\mathrm{CuO}$ Nanoparticles by Novel Sol-Gel Technique ", JOURNAL OF NANO- and ELECTRONIC PHYSICS, Vol. 4. Issue. 3, pp. 03006-1-03006-7, 2012

[19] C.Y. Chiang, K. Aroh, N. Franson, V. R. Satsangi, S. Dass, S. Ehrman, "Copper oxide nanoparticles made by flame spray pyrolysis for photochemical water splitting-Part II. Photochemical study", International journal of hydrogen energy, Vol. 36 ,Issue. 24, pp.15519-15526, 2011

[20] E. Shahsavani, N. Feizi, A. D. Khalaji, "Copper Oxide Nanoparticles Prepared by Solid State Thermal Decomposition:", Journal of Ultrafine Grained and Nanostructured Materials, Vol. 49, Issue. 1, pp. 48-50, 2016

[21] K. Kannaki, P. S. Ramesh, D. Geetha, "Hydrothermal synthesis of $\mathrm{CuO}$ Nanostructure and Their Characterizations",Internation Journal of Scientific \& Engineering Research, Vol. 3, Issue. 9, pp. 616-619, 2012

[22] S. Senthilarasu, R. Sathyamoorthy, S. Lalitha, "Synthesis and characterization of $\beta-\mathrm{FeSi}_{2}$ grown by thermal annealing of $\mathrm{Fe} / \mathrm{Si}_{2}$ bilayers for photovoltaic applications", Solar Energy Materials \& Solar Cells, Vol. 82, pp. 299-305, 2004

[23] K.J. Arun, A.K. Batra, A. Krishna,, K. Bhat, M. D. Aggarwal, P. J. Joseph Francis,"Surfactant Free Hydrothermal Synthesis of Copper Oxide Nanoparticles", American Journal of materials science, Vol.5,Issue.(3A), pp.36-38, 2015

[24] K. Kannaki, P. S. Ramesh , D. Geetha,"Hydrothermal synthesis of $\mathrm{CuO}$ Nanostructure and Their Chacterizations", International Journal of Scientific \& Engineering Research Volume3, issue 9, pp. 616-619, September-2012.

[25] P. K. Mochahari, "Investigation of Structural and Spectroscopic Properties of Nanostructured CdS Films", International Journal of Scientific Research in Physics and Applied Sciences, Vol. 5, Issue. 6, pp. 1-6, 2017

[26] A. Jagminas, J. Kuzmarskyt, G. Niaura, “ Electrochemical formation and characterization of copper oxygenous compounds in alumina template from ethanolamine solutions", Applied Surface Science, Vol.201, Issues. 1-4, pp. 129-137,2002

[27] Jagminas A, Niaura G, Kuzmarskyt J, Butkiene R. "Surfaceenhanced Raman scattering effect for copper oxygenous compounds array within the alumina template pores synthesized by ac deposiation from $\mathrm{Cu}$ (II) acetate solution", Applied Surface Science, Vol. 225, Issues. 1-4, pp.302-308. 2004

[28] Y. C. Zhang, J. Y. Tang, G. L. Wang, M. Zhang, X. Y. Hu, “ Facile synthesis of submicron $\mathrm{Cu}_{2} \mathrm{O}$ and $\mathrm{CuO}$ crystallites from a solid metallorganic molecular precursor", Journal of Crystal Growth, Vol. 294, Issue.2, pp. 278-282, 2006
[29] A. A. Radhakrishnan, B. B. Beena , "Structural and Optical Absorption Analysis of CuONanoparticles", Indian journal of Advances in Chemical Science, Vol. 2, Issue. 2, pp. 158-161, 2014

[30] N. R. Dhineshbabu, V. Rajendran, N. Nithyavathy, R. Vetumperumal, "Study of structural and optical properties of cupric oxide Nanoparticles", Applied Nanoscience, Vol. 6, Issue.6, pp. 933-939, 2016

[31] Mushtaq A. Dar, Sang H. Nam, Youn S. Kim, Won Bae Kim, "Synthesis, Characterization and electrochemical properties of self-assembled leaf-like $\mathrm{CuO}$ nanostructures", Journal of Solid State Electrochemistry, Vol. 14, Issue. 9, pp. 1719-1726, 2010

[32] Taman R, Ossman ME, Mansour MS, Farag HA, “ Metal Oxide Nano-particles as an Adsorbent for Removal of Heavy Metals", Journal of Advanced Chemical Engineering, Vol. 5, Issue.3, pp. 125,2015 